\title{
HECHICERAS DE CERVANTES, FAUSTOS HISPANOS Y ROSAS DE INVIERNO ${ }^{1}$
}

\author{
José Manuel Pedrosa \\ Universidad de Alcalá \\ josem.pedrosa@uah.es
}

\section{La Camacha de Montilla, o CeRVANTES EN El ESPEjo de los Clásicos (Y DE ALGÚN CONTEMPORÁNEO SUYO)}

$\mathrm{E}$ 1 elenco de las potencias mágicas que atribuyó el perro Berganza a la Camacha, hechicera del pueblo cordobés de Montilla, en la Novela ejemplar cervantina de El coloquio de los perros, tiene, entre otros méritos, el de que participa de lo que pudiéramos llamar, por lo menos en términos relativos, autenticidad o legitimidad folclórica.

En una época, la que se sitúa entre el Renacimiento y el Barroco, en que algunas de las tradiciones literarias dominantes (la novella de enredo amoroso, el libro de caballerías, el libro de pastores, la fantasía mitológica, la comedia o el drama con ingredientes mágicos o sobrenaturales...) solían comunicar representaciones más bien tópicas, edulcoradas y pasadas por el filtro de lo cortesano de las mujeres-magas, la Camacha a la que Cervantes opone, con sutil ironía, los parangones clásicos de Erito, Circe o Medea, es una bruja más real o más realista, más cruda y desgreñada, más de los bajos fondos, más adornada de las potencias que, sin tantas ínfulas novelescas ni remilgos cortesanos, asociaba el vulgo al oficio hechiceril:

\footnotetext{
$1 \quad$ Este artículo se ha desarrollado dentro del proyecto «La mujer frente a la Inquisición española y novohispana» (FEM2016-78192-P), I+D de Excelencia del Ministerio de Economía y Competitividad (MINECO), financiado por la Agencia Estatal de Investigación (AEI) y el Fondo Europeo de Desarrollo Regional (FEDER, UE). Agradezco su ayuda a José Luis Garrosa, Óscar Abenójar, Félix Francisco Castro Vicente y Emilio Blanco.
}

Edad de Oro, XXXVIII (2019), pp. 125-158, ISSN: 0212-0429 - ISSNe: 2605-3314

DOI http://doi.org/10.15366/edadoro2019.38.007 
Has de saber, hijo, que en esta villa vivió la más famosa hechicera que hubo en el mundo a quien llamaron la Camacha de Montilla; fue tan única en su oficio, que las Eritos, las Circes, las Medeas, de quien he oído decir que están las historias llenas, no la igualaron. Ella congelaba las nubes cuando quería, cubriendo con ellas la faz del sol; y cuando se le antojaba, volvía sereno el más turbado cielo; traía los hombres en un instante de lejas tierras; remediaba maravillosamente las doncellas que habían tenido algún descuido en guardar su entereza; cubría a las viudas de modo que con honestidad fuesen deshonestas; descasaba las casadas, y casaba las que ella quería. Por diciembre tenía rosas frescas en su jardín y por enero segaba trigo (Cervantes 2013: 591-592).

El comentario de cada uno de los atributos hechiceriles (la serie continúa más allá de lo que yo extracto) que fue asociando el perro Berganza a la polifacética Camacha de Montilla daría para llenar un sinfín de páginas. Pero habremos de ceñirnos al intento de desentrañamiento de uno solo de los méritos que adornaban el currículum de la hechicera: el de que «por diciembre tenía rosas frescas en su jardín y por enero segaba trigo». Tiempo habrá, en el futuro, de seguir hurgando en lo demás del currículum de la Camacha.

Nuestro punto de partida ineludible debe ser el comentario eruditísimo que acerca de la magia concreta de hacer prosperar rosas y trigos invernales urdió Soledad Pérez-Abadín Barro en un gran ensayo de 2006 acerca de la hechicería cervantina en el contexto de la gran literatura de su época y del corpus mágico grecolatino. La cita es densa y extensa, pero indispensable, y nos va a conducir por todo un muestrario de clásicos y de contemporáneos de Cervantes: de Ovidio a Boccaccio y Sannazaro, y de Séneca a Lope y Bernardo de Valbuena:

Quedan por considerar dos competencias, ajenas a las tercerías, que completan la semblanza de Camacha: «Por diciembre tenía rosas frescas en su jardín y por enero segaba trigo. Esto de hacer nacer berros en una artesa era lo menos que ella hacía». Aunque la vecchia de la Arcadia [de Jacopo Sannazaro] maneja los ciclos naturales y los elementos, no está investida de esos poderes específicos, que, al igual que los restantes, se documentan en variedad de fuentes. La alteración de las estaciones evoca el filtro de Medea, capaz de reverdecer un viejo leño al mismo tiempo que la sangre de su suegro Esón, según relatan las Metamorfosis de Ovidio en un pasaje imitado en el Filoloco de Boccaccio (IV, 4), en donde se atribuye a Tebano la capacidad de alterar el ritmo de las estaciones: «Io ho al presente mestieri di sughi d'erbe, per li quali l'arida terra prima dall'autunno e poi dal freddissimo verno de' suoi fiori, frutti ed erbe spogliata, faccia in parte ritornare fiorita, mostrando, avanti il dovuto termine, primavera» (p. 850).

Esta pócima hace florecer el terreno sobre el que se derrama: «e tanto più ancora avea operato la virtù degli sparti liquori, che i frutti, i quali l'agosto suole producere, quivi nel salvatico tempo tutti il loro alberi facevano belli» (p. 852). Con similar valor de prueba, este artificio se ilustra en otro relato del Decameron, 
tal como sumariza su epigrafe: «Madonna Dianora domanda a messer Ansaldo un Giardino di gennaio bello come di maggio; messer Ansaldo con l'obligarsi a uno nigromante gliele dà».

Asimismo, en la tragedia de Séneca que lleva su nombre, la hija de Eetes proclama su dominio sobre los ritmos estacionales: «Temporum flexit vices: / aestiva tellus floruit cantu meo, / messem coacta vidit hibernam Ceres». En Hércules en el $E t a$, la nodriza incluye entre los efectos de sus prácticas mágicas la anticipación de la primavera: «uernare iussi frigore in medio nemus / missumque fulmen stare» y Deyanira admite ese poder del canto mágico: «et bruma meses uideat».

Ovidio, Séneca y Boccaccio pudieron sugerir las alteraciones estacionales obradas por la Camacha, que en El peregrino en su patria de Lope de Vega se clasifican entre los logros de la magia natural, «aplicando los activos y pasivos a su sazón y tiempo, como hacer que nazcan rosas por enero o que por mayo estén las uvas maduras, anticipando el tiempo estatuido de la naturaleza» (I, p. 142). El motivo de las rosas invierte su funcionalidad en la égloga $\mathrm{V}$ de $\mathrm{El}$ siglo de oro en las selvas de Erifile de Bernardo de Balbuena, en un canto de Tirsis acerca de la magia, que renueva al mismo tiempo que devasta el paisaje fuera de sazón: «vestir nuestros collados de alegría, / en el invierno estéril y el verano, / las rosas ahogar en nieve fría»; "y con su canto / dejar deseco el campo florecido, / bajar los pinos a escuchar su canto, / trocar las mieses y encantar los ríos» (vv. 104-107, f. 92r) (Pérez-Abadín Barro 2006: 96-97).

Me tomaré la libertad de añadir a esta densa nómina erudita un par de referencias más, que nos permitirán ensanchar el espectro de nuestras indagaciones y comparaciones. Empezaremos por unos versos del canto XXIII de la Segunda Parte de La Araucana (1578) de Alonso de Ercilla, que prestan su voz a un viejo taumaturgo araucano, troglodita y de nombre Guaticolo, de currículum mágico abultado. Seleccionamos estos méritos, de entre la extensa enumeración:

Las yerbas en su agosto reverdece

y entiende la virtud de cada una;

el mar revuelve, el viento le obedece

contra la fuerza y orden de la luna...

(Ercilla 1993: 637 y 639).

De la poesía épica saltamos a la satírica: Jesús Antonio Cid ha estudiado en detalle un poema para glosar del originalísimo poeta tardobarroco Juan Vélez de León (1655-1736), que rezaba así:

En el rigor del ibierno, cuando hace el frio mayor,

puede criar una flor

Cristo en la punta de un cuerno. 
¿Cristo con atributos de magos y demonios, y obrando milagros sobre un cuerno? Sí, por raro que suene. Cid ha desentrañado ciertos ingredientes del entorno poético e ideológico en que fueron compuestos estos versos que ayudan a interpretar mejor su sesgo antirreligioso, y ha recuperado algunos hilos de su fascinante deriva plurisecular e internacional en el seno de diversas tradiciones orales: paralelos suyos inconfundibles, aunque con matices y glosas diferentes (que no tengo espacio para reproducir aquí, aunque son fascinantes), fueron, en efecto, entonados por campesinos mexicanos y portugueses a lo largo del siglo xx (Cid 2011: 180 y 189-190). Misterios, casi magias, de la tradición oral.

\section{EN EL PRINCIPIO FUE... EL CUENTO FOLCLÓRICO}

No cabe duda de que poner a la cervantina Camacha de Montilla frente al espejo de los clásicos (y de alguno de sus contemporáneos, como Lope), según hizo Soledad Pérez-Abadín Barro, es una cuestión de justicia si se aspira a llegar hasta la entraña del personaje y de su currículum mágico, así como de la cultura y la técnica literaria de Cervantes. Pero tampoco cabe dudar de que antes de Cervantes y antes incluso de los clásicos que desbrozaron su camino, estaba el manantial del cuento folclórico, del cual obtuvieron toda esa plétora de autores clásicos y modernos la inspiración y los argumentos, conforme aspiro a probar.

Jorge García López, el editor del texto cervantino cuya versión hemos seguido, glosó con una nota escueta, pero significativa, la sentencia del «por diciembre tenía rosas frescas en su jardín y por enero segaba trigo» y, en vez de inclinarse por la comparación con clásicos y contemporáneos, optó por indicar la relación con el motivo folclórico que tiene el número H.1023.3 en el Motif-Index de Stith Thompson. Daba así a entender que, a su juicio, en el cuento folclórico debía de estar la raíz de todo.

Añadiré yo el esquemático desglose (García López lo omitió) que de ese motivo hace el tal catálogo de Thompson:

H1023.3. †H1023.3. Task: bringing berries (fruit, roses) in winter. *Type 403B, 480, *Roberts 134; BP I 99ff., II 232; *Saintyves Perrault 20; De Vries FFC LXXIII 269 n. 2; Irish myth: *Cross; India: Thompson-Balys; Japanese: Ikeda; Eskimo (Greenland): Rink 159; N. A. Indian: *Thompson Tales 313 n. 126c.

Toda esta extraña sopa de siglas, números y asteriscos, que no nos detendremos a desentrañar, viene en sustancia a querer decir que han sido documentados en tradiciones orales de varias partes del mundo relatos folclóricos en que se halla engastado el motivo de la prueba de encontrar alguna flor o alguna planta de fuera de temporada: desde Irlanda hasta Japón, Groenlandia y los repertorios de los pueblos nativos de Norteamérica. 
Se deduce también del esquema elaborado por Thompson que el motivo suele adherirse de manera recurrente a los tipos cuentísticos que tienen los números 403B (el cual acabó absorbido, en el índice de Uther, por el tipo ATU 403: The Black and the White Bride, «La novia negra y la novia blanca») y ATU 480 (The Kind and the Unkind Girls, «Las niñas amable y descortés») del catálogo de Aarne-Thompson-Uther. Los avatares de ambos cuentos, con los episodios de las germinaciones y floraciones fuera del orden natural, narrados en un sinnúmero de lenguas, se hallan igualmente dispersos por los cuatro puntos cardinales.

No nos detendremos aquí en el desarrollo de las pistas y referencias pluriculturales (Irlanda, India, Japón, Groenlandia...) que estaban cifradas en el Motif-Index de Thompson. Lo que no estará de más será hacer alguna indagación en torno a alguna de las versiones, principalmente si son hispánicas, en que se halla engastado el motivo.

En nuestra lengua, las versiones del cuento ATU 403B, «La novia negra y la novia blanca», son rarísimas. De hecho, en el gran catálogo de cuentos del mundo hispánico de Julio Camarena Laucirica y Maxime Chevalier solo aparecen indexadas una versión asturiana, dos catalanas, una vasca, una sefardí y una chilena (1995: n. ${ }^{\circ}$ 403B). Para el propósito que ahora nos guía, bastará reproducir el episodio de la versión vasca (traducida al castellano) en que la odiosa madrastra envía a su hijastra a por frutas invernales:

Una vez, en pleno invierno, envió a esta vestida de traje de papel y descalza a recoger fresas, encargándole trajera un cesto de ellas. La pobre muchacha fue temblando de puro frío y encontró a tres hombres en una choza.

- ¿Adónde vas, muchacha? - le preguntaron.

- La madre me ha enviado a por fresas.

— ¡A por fresas! ¡Con el frío que hace y con el vestido que tienes! ¿Qué clase de madre es esa?

-Es mi madrastra.

— ¡Ah, ya! Pues ahí mismo, bajo las leñas de detrás de la choza hallarás tales fresas, por lo menos para llenar un cesto.

Cuando llenó colmadamente de hermosas fresas el cestito, fue a los tres hombres a darles las gracias (Azkue 1989: II, n. ${ }^{\circ}$ 2).

El cuento ATU 480, el de «Las niñas amable y descortés», sí tiene un dosier muy profuso, en el dominio hispánico y en casi todo el mundo. Camarena y Chevalier catalogaron docenas de versiones en castellano, en catalán, en gallego, en vasco y en sefardí, y muchas hispanoamericanas y portuguesas (1995: n. ${ }^{\circ} 480$ ).

El etnógrafo murciano Anselmo J. Sánchez Ferra amplió muy sustancialmente el elenco de referencias de las versiones hispánicas. He aquí el arranque de una, cuyas protagonistas llevan los nombres de Blancaflor y Javiera, que Sánchez Ferra registró de la voz de una mujer de Murcia: 
Y una mañana de frío la madrastra le dijo a Blancaflor:

- Mira, te vas a ir con esta cesta con la merienda y hasta que no me traigas la cesta llena de fresas no vuelvas.

Y para que se fuera, en medio de la nieve, le puso un traje de papel. Claro, ella cuando se vio en la nieve dijo:

- Madre mía, pero yo cómo voy a llenar la cesta de fresas si todo está helado.

Pero como era buena y obediente pues empezó a andar a ver lo que pasaba, con muchísimo frío, hasta que andando, andando llegó a una casita que estaba allí en el bosque y se puso a dar vueltas. Y entonces dentro vivían tres enanitos que al verla le dijeron:

- ¡Muchacha, pasa, pasa, qué haces tú ahí en la nieve con el frío que hace!

$\mathrm{Y}$ entonces Blancaflor les contó lo que había pasado.

- Pues nada, es que mi madrastra me ha dicho que tengo que llenar la cesta de fresas.

-Madre mía, vamos a ver, ¿nos das de tu merienda?

Y la niña les dijo:

-Pues claro.

Y compartieron los mendrugos que llevaba, porque no le había echado otra cosa. Entonces los enanitos le dijeron:

- Siéntate aquí y no te preocupes.

Le cogieron la cesta, se fueron y al rato vinieron y le dijeron:

-Mira, ya tienes las fresas.

—Ah, pues muchas gracias (Sánchez Ferra 2013-2014: I, n. $\left.{ }^{\circ} 93\right)^{2}$.

Añadiré yo aquí una información que se le pasó por alto a Thompson: alguna que otra rara versión del cuento que en el antiguo catálogo tipológico de Aarne-Thompson tenía el número AT 533* (The Snake Helper, «La culebra ayudante») y que en el catálogo actualizado de Aarne-Thompson-Uther tiene el número ATU 404 (The Blinded Bride, «La novia a la que dejan ciega») lleva engastado también el motivo de la prueba de la petición de frutas extemporáneas. Señal adicional de la volatilidad del motivo. Una versión del pueblo cacereño de Trujillo hablaba, así, de una maravillosa «culebrita» que explicaba a una muchacha cómo debía conseguir, en la sierra y en pleno mes de enero, una cesta de higos frescos que le ayudarían a redimirse y a dar un vuelco a su destino (Curiel Merchán 1987: n. $\left.{ }^{\circ} 136,488-489\right)^{3}$.

Conozco además un cuento tradicional tunecino que formaba parte del asombroso repertorio de Lela Ula, narradora de las más importantes de las que hayan sido registradas (por el gran folclorista tunecino Mohamed Abdelkefi) en

\footnotetext{
2 Véase, en su aparato crítico, el detalle de versiones que no aparecían en el catálogo de Camarena Laucirica y Chevalier.

3 Sobre esta tipología de cuento, véase Agúndez García (1998: 193-198).
} 
cualquier época y lugar, que incorporaba también, y en una posición central dentro de la trama, el motivo. El cuento lleva el título de La justicia divina, y es una versión muy original de, como mínimo, el tipo ATU 960, The Sun Brings All to Light, «El sol todo lo saca a la luz».

Muy en resumen: Lela Ula narraba cómo un mercader mató por puro capricho a otro mercader amigo, judío, mientras iban los dos de viaje. Antes de morir, el judío aseguró al criminal que, al cabo de muchos años, Dios castigaría su crimen. Pasó el tiempo y el asesino, muy enriquecido, decidió regresar a su país:

Vendió su comercio, recogió todo lo que era suyo y se puso en camino. Al llegar a la altura del lugar en el que había matado y enterrado a su compañero, vio que allí había crecido una gran parra, verde y florida, y que de ella colgaban, fuera de época, unos racimos de uvas grandes, limpias, casi transparentes, apetitosas.

«Esto sí que tener suerte», se dijo para sí. «Estas uvas tan buenas y fuera de temporada harán las delicias de quien las tome. Voy a cortarlas y cuando llegue a mi país entregaré algunos racimos al sultán, quien seguramente me dará una buena recompensa».

Pues eso es lo que hizo. Se llevó consigo unos racimos de uvas, bien cuidados y protegidos, y siguió su camino (Abdelkefi 2019) ${ }^{4}$.

El desenlace del cuento de Lela Ula es de enorme patetismo y muestra, dicho sea de paso, analogías sorprendentes con el célebre relato La cabeza del cordero de Francisco Ayala, quien posiblemente tomara como fuente de inspiración alguna narración oral de la familia del cuento tunecino: al destapar el asesino tunecino la cesta en la que había colocado las uvas de fuera de temporada, ante las miradas ansiosas de quienes iban a ser sus convidados (el sultán y su corte), las que quedaron al descubierto fueron, por designio de Dios, la cabeza del judío muerto y la acción criminal del mercader, que fue condenado a muerte por ello.

El cuento tunecino de La justicia divina es, en fin, una tesela singularísima de nuestro disperso mosaico de relatos. Es, de hecho, el único (si descontamos algunas reminiscencias que pueden detectarse en el remate del mito de Gilgamesh, del que hablaremos) en que al proveedor de uvas exóticas y a destiempo le salen mal las cosas en el momento crítico: el del convite con la exhibición apoteósica de su poder ante los demás. Ninguno de los sujetos mágicos que ya hemos conocido ni de los que seguiremos conociendo sufrió jamás, en el momento más crítico, accidente parecido. Imaginemos las caras que hubiesen puesto san Alberto Magno, Gagüino Catón, Fausto o el cura de El Viso (de quienes tendremos noticias) y sus convidados si, en el momento tan esperado de la revelación en la mesa de las frutas prodigiosas, lo que aflorase fuese magia averiada podredumbre cadavérica.

$4 \quad$ Acerca de la vida y de los cuentos de Lela Ula, véase Abdelkefi (2018). 


\section{Los disfraces de la letra libresca: de Boccaccio a María de Zayas}

Los tres tipos de cuentos folclóricos con documentación española (ATU 403, ATU 480 y ATU 404) sobre los que hemos llamado la atención en páginas anteriores se acogen a dos modalidades de tramas básicas cuyas líneas maestras comparten ingredientes relevantes: el primero y el segundo nos presentan a una niña huérfana que sufre el hostigamiento de una madrastra que la envía a buscar fresas en los meses de invierno; la niña recibe el auxilio mágico de tres hombres misteriosos (en el cuento primero) y de tres enanitos (en el segundo), que traen de algún lugar lejano o mágico las frutas insólitas. El cuento tercero está protagonizado por una joven huérfana y maltratada por su tía y por su prima que recibe, en cambio, el auxilio de una «culebrita» maravillosa que le entrega una partida de higos frescos invernales: un requisito indispensable para la sanación de la muchacha y para el reencuentro y el matrimonio con el príncipe que la ama.

Las frutas a destiempo, la mujer que las solicita, el auxiliar mágico que se encarga de conseguirlas, forman, de este modo, una especie de esquema con tres ángulos que veremos muchas veces reciclado en las páginas que seguirán. Sin ir más lejos, en las muy características escenas de varios hitos de la narrativa de signo fáustico, que nos mostrarán a una dama que pide a un varón (a Fausto o a algún avatar suyo) uvas maduras en el tiempo invernal: un manjar que el diabólico Mefistófeles (o algún otro ayudante sobrenatural) no tiene impedimento en traer casi al instante desde el otro extremo del mundo.

Es destacable que las leyendas del ciclo fáustico que conoceremos, al igual que los cuentos de Boccaccio y Zayas que vamos enseguida a analizar, incorporen un cuarto elemento principal (el galán simplemente servicial y obsequioso del complejo de Fausto, o el galán locamente enamorado de Boccaccio y Zayas) al esquema que en el cuento folclórico de carácter maravilloso se apoyaba sobre tres pilares esenciales. Porque resulta que en los cuentos ATU 403, ATU 480 y ATU 404 que hemos analizado el auxiliar mágico ponía la fruta extemporánea directamente en las manos de la joven protagonista, sin que hubiese necesidad de intermediario. En muchos relatos que nos quedan por conocer (Boccaccio, Zayas, ciclo de Fausto, etc.), el auxiliar mágico entrega, en cambio, la fruta a un hombre que asume la función de mediador con respecto a la mujer. Ello tiene el efecto notable del enriquecimiento de la trama con un nuevo y fascinante tópico, que me limitaré a identificar de manera muy sucinta: el de la universalidad de las relaciones de poder $\mathrm{o}$, si se quiere, el de la jerarquización social y política que atañe también a los amos y a los servidores del más allá, y no solo a los de aquí.

Ocupa un lugar muy destacado dentro de esta tradición el cuento X:5 del Decamerón de Boccaccio, aquel cuyo título María Hernández Esteban, en su edición canónica en español, tradujo de este modo: 
Doña Dionara le pide a micer Ansaldo un jardín en enero tan bonito como si fuese de mayo; micer Ansaldo, comprometiéndose con un nigromante, se lo consigue; el marido le permite que ella acceda a los deseos de micer Ansaldo, quien, al saber la liberalidad del marido, la libera de su promesa, y el nigromante, sin querer nada de lo que le pertenece, libera del pago a micer Ansaldo.

No contamos con espacio aquí más que para, con respecto al relato del Decamerón, dejar apuntadas las muy significativas palabras que la exigente doña Dianora dirigió al voluntarioso micer Ansaldo:

Lo que deseo es esto: quiero el próximo mes de enero, cerca de esta ciudad, un jardín lleno de hierba verde, de flores y de frondosos árboles, como si estuviéramos en mayo.

Tan pronto supo el enamorado las pretensiones de la amada, se aplicó a la tarea de contratar al auxiliar mágico: un hábil nigromante que logró que

la noche siguiente al primero de enero, apareciese por la mañana, según atestiguaban los que lo veían, uno de los más bellos jardines que jamás nadie hubiese visto, con hierba y con árboles y con frutos de todo tipo. Y cuando micer Ansaldo, muy contento, lo vio, haciendo coger de los mejores frutos y de las más bellas flores que en él había, ocultamente se los hizo ofrecer a su señora e invitarla a ver el jardín de que ella había solicitado, para que por él comprendiese que la amaba (Boccaccio 1998: 1.074-1.075).

«Los mejores frutos y las más bellas flores» brotados admirablemente en el mes de enero, la mujer (aquí no la niña huérfana del cuento folclórico, sino una burguesa displicente, porque está enamorada de su marido y no de su pretendiente) que los solicita, y el auxiliar mágico (aquí un nigromante) que se da prisa en el acarreo, vuelven a ser agentes clave en el cuento de Boccaccio, al que además se incorpora con claridad el cuarto elemento que no aparecía o que quedaba borroso en los cuentos folclóricos: el galán intermediario que desea satisfacer el capricho de la dama. Aquí es Ansaldo, como lo será don Jorge en el cuento de Zayas, o Fausto, o Gagüino Catón (y sus avatares) en los ciclos narrativos a los que enseguida nos asomaremos.

Ingredientes y vínculos análogos se pueden apreciar en El jardín engañoso, un relato engastado en la colección de Novelas amorosas y ejemplares (1637) de María de Zayas y que, como demostró María Hernández Esteban, está directamente ahormado sobre el modelo de Boccaccio. Los ingredientes son prácticamente los

5 Acerca de este relato de Boccaccio, véanse Marcus (1980), Borghello (2001), Laroche (2003) y Bonazzi (2014). 
mismos: las flores y los árboles insólitos y nacidos en una sola noche, la dama casada y exigente para con su inoportuno pretendiente (doña Constanza), el impetuoso galán puesto a su servicio (don Jorge) y el auxiliar mágico, que en esta ocasión no es un nigromante, sino el mismísimo diablo.

He aquí las peticiones que exige la hastiada doña Constanza a su pretendiente don Jorge:

- Hagamos, señor don Jorge, un concierto; y sea que como vos me hagáis en esta placeta que está delante de mi casa, de aquí a la mañana, un jardín tan adornado de cuadros y olorosas flores, árboles y fuentes, que ni en su frescura ni belleza, ni en la diversidad de pájaros que en él haya, desdiga de los nombrados pensiles de Babilonia que Semíramis hizo sobre sus muros, yo me pondré en vuestro poder y haré por vos cuanto deseáis (Zayas 2007: 527).

Gracias a un pacto establecido con el mismísimo diablo, don Jorge logró cumplir con el maravilloso encargo y satisfacer las exigencias de su dama. No estará de más señalar que, al final, todo el enredo fue a dar en un colofón feliz y dulcificado, calcado prácticamente del desenlace del cuento boccacciano: don Jorge liberó a doña Constanza de su compromiso, para que pudiera seguir consagrada a su feliz vida de esposa, y el diablo acabó eximiendo al temerario galán de las consecuencias de su pacto.

Es desenlace que da que pensar. La salvación in extremis del alma de algunos Faustos (el de Goethe, por ejemplo) y don Juanes (el de Zorrilla) tardíos, en contraposición con los finales crudos e implacables que habían conocido sus antecesores, se ha estimado a veces que fue concesión al gusto burgués, acomodado, contemporizador de los receptores del siglo xix. No es así, o no es por completo así: el experimento de la condonación de la condena del galán impío venía siendo ensayado desde Boccaccio y Zayas, por lo menos.

\section{El agua del JoRdán \\ Que ANTONio de Santarem trajo para su amada (Siglo XiII) \\ Y EL MITO DE LA BÚSQUEDA DEL AGUA DE LA VIDA}

Aunque sea esa una dimensión en la que no se ha indagado lo suficiente, los relatos de Boccaccio y Zayas tuvieron sus antecedentes orales y escritos. Nos fijaremos, ahora, en uno: dentro de un tratado redactado entre 1279 y 1282 (Historia canonica et civilis ou Liber illustrium personarum), el franciscano Juan Gil de

6 Sobre este cuento de Zayas, es imprescindible el estudio de Paba (2013) y también Paredes Monleón (2014). 
Zamora puso por escrito una novelesca cuasi-hagiografía en latín (Antonius Santarenensis de Ordine Minorum), plagada de peripecias maravillosas, de un franciscano portugués, Antonio de Santarem (que no tiene al parecer nada que ver con Gil de Santarem, 1190-1265, el dominico en cuya leyenda se han señalado ecos fáusticos), que había fallecido poco antes, en 1278. A ella tiene sentido que atendamos justo aquí.

De Jean-Marie Sansterre, el último filólogo que ha estudiado esa vita en detalle, tomamos esta síntesis del inicio de la trama:

Hombre noble y educado, Antonio ardía de amor por una mujer muy hermosa. Cuando él le declaró su amor, ella bromeó con que consentiría si él marchase primero al río Jordán para lavarse en él, puesto que tenía una apariencia muy negra. Antonio marchó, se lavó en el río Jordán y regresó a Portugal con un jarro que contenía agua del río, el cual ofreció a la señora.

Admirada por una proeza y por un amor tan enormes, se casó con él. El matrimonio fue consumado y los esposos vivieron en compañía durante algún tiempo. Cuando su esposa murió, Antonio renunció a todo y entró en la orden de San Francisco (Sansterre 2019: 3) ${ }^{7}$.

Viene a continuación una narración extensa, compleja y desmesurada, en la que nos guardaremos mucho de entrar y en la que se hace el seguimiento de la lucha sin cuartel que mantuvo Antonio de Santarem con el falso santo Domingo de Elvas, quien había pactado con el diablo para engañar con milagros e invenciones ilusorios al vulgo.

Lo que a nosotros más nos interesa es, lógicamente, la llamativa coincidencia de ciertos motivos esenciales de los cuentos de Boccaccio y Zayas con la secuencia del relato de Gil de Zamora que presenta a una dama que, entre burlas y veras, impone a su pretendiente una prueba de cumplimiento casi imposible, que se salda con un viaje de ida y vuelta al otro extremo del mundo para obtener y acarrear cierta agua carismática.

Es cierto que no faltan, en el relato, las innovaciones que buscan (con éxito solo mediano) depurar los ingredientes mágicos y poner todo el énfasis sobre los más pretendidamente religiosos: el amante, que acabará siendo un clérigo célebre, emprende él solo el peligroso viaje, para no tener que depender de ningún auxiliar dado a magias ni diablerías; el baño en las aguas del Jordán, que se tenían por milagrosas (muchas personas católicas siguen fieles hoy a esa creencia y los miembros de varias monarquías europeas, entre ellas la española, siguen siendo bautizados con el agua traída del río Jordán), limpia a Antonio de su presunta negritud,

7 La vida de Antonio de Santarem, según Gil de Zamora, está traducida en López (1915); véase también su resumen y comentario en Pérez-Embid Wamba (2002: 324-330). 
aunque lo más lógico fuera interpretar que lo limpia de sus pecados anteriores (incluido el de desenfreno amoroso); y la dama que, conmovida ante tal muestra de amor, acaba enamorándose y casándose santamente con él y muriendo oportunamente, para que el viudo pudiese dar inicio a su vida consagrada.

El arranque de la vita de Antonio de Santarem puebla con figuras y sucesos interesantes nuestro paisaje. Su aportación más significativa: la confirmación de que los motivos narrativos que pasarían a Boccaccio y Zayas debían de llevar siglos flotando en el medio ambiente oral internacional. Porque la reescritura que elaboró Gil de Zamora en el siglo XIII es adaptación incuestionable, al registro clerical, de todo un batiburrillo de motivos folclóricos orales, profanos, consuetudinarios.

Pero además la expedición de Antonio para purificarse y traer el agua del remoto río Jordán apunta en una dirección que puede tener un significado todavía más trascendente: el de que nos hallamos en espacios de confluencia con el motivo de la búsqueda en el más allá del agua de la vida, de la inmortalidad, de la resurrección, de la juventud, que es tópico nuclear en un repertorio de cuentos maravillosos que se halla documentado en el mundo entero.

Más aún: si estamos en espacios de confluencia con el motivo de la búsqueda de aguas maravillosas en los confines del mundo, nos hallamos también en terrenos anejos a los que (allá por el 2700 a. C.) dice la tradición que pisó el primer héroe del que la humanidad guarda recuerdo nítido y coherente: el sumerio Gilgamesh, quien se lanzó a la búsqueda de la planta de la inmortalidad, una especie de lirio con espinas como las de las rosas, que se hallaba en el fondo de unas aguas misteriosamente localizadas en el más allá.

Para mayor abundamiento: la planta de la inmortalidad que Gilgamesh logró sacar del fondo de aquellas aguas llegó, sí, hasta la orilla de acá, pero (devorada por una serpiente) se esfumó en el camino de Uruk: no dio tiempo, pues, a que pudiese ser exhibida ni degustada ni compartida por Gilgamesh, en ocasión apoteósica frente a los suyos. Dramático contraste con algunas de las rosas, uvas o higos de otros relatos que estamos conociendo y que sí alcanzaron a ser contemplados o degustados por algunos humanos y por sus convidados, aunque fuese en eventos y cenas muy efímeras.

En el antiquísimo relato sumerio hay otro elemento digno de destacar: el que Gilgamesh haga en solitario el viaje hasta las aguas situadas en el más allá. Enkidu, su compañero sobrehumano habitual, no pudo ponerse a su servicio en aquella expedición porque había muerto al regreso de una aventura anterior. Tampoco recibió Gilgamesh el auxilio de ningún ave prodigiosa, del tipo de las que en muchos cuentos maravillosos traen para el héroe el agua del más allá.

Gilgamesh hizo pues el viaje en soledad equiparable a la de Antonio de Santarem, quien fue expedicionario de muchos siglos después. La diferencia estuvo 
en que la planta mágica del primero se desvaneció por el camino —era lógico, en el marco de un mito escatológico que buscaba narrar el final de la estirpe de los dioses inmortales - antes de que llegase a ser contemplada por ojos mortales, mientras que el agua mágica del segundo - que operaba en el registro positivo de la narración católica de milagros - sí llegó a su destino y cumplió con su carismática función de purificación, conversión y puesta al servicio de la propaganda católica.

Si se contempla desde este marco, la expedición de Antonio de Santarem para traer el agua maravillosa del río Jordán a Portugal viene a ser, además de un texto precursor de otros que conoceremos, una propuesta original y fascinante de acercamiento a la raíz del cuento maravilloso, al origen del mito.

\section{LA MUJER ADÚLTERA QUE MANDABA A SU MARIDO}

A BUSCAR CHIRLOS MIRLOS AL MAR

La expedición del amante a alguna remota corriente de agua para traer a la mujer amada una botella con el propio líquido o alguna planta o criatura acuáticas y de difícil localización tampoco ha dejado de llamar, por lo demás, a la inversión paródica. El apunte que consignaré será muy breve, porque hay ya bibliografía crítica al respecto (Chevalier 1979: 158; Cid 1985; Pedrosa 1995). Dejaré constancia nada más de que existe un cuento folclórico de difusión internacional, el conocido como ATU 1360C, Old Hildebrand, que está protagonizado por una mujer adúltera que gusta de enviar a su marido a hacer búsquedas extravagantes en geografías remotas (muchas veces acuáticas), mientras ella se queda en casa con su amante. La inversión, o la subversión (amor / adulterio, heroísmo / estupidez, épica / chiste) con respecto a los modelos que hemos conocido, es absoluta.

Cabe añadir que la materia argumental e ideológica de la que está hecha este tipo de relato tiene conexión con las bromas, arraigadísimas hasta hoy en muchas tradiciones de Europa, de enviar a las personas inocentes o inexpertas, el día primero de abril, en busca del «pez de abril»; o con las bromas, que fueron muy tradicionales en España, de mandar a algún tonto a «buscar gamusinos» quiméricos, en las cercanías de algún espacio acuático por lo general.

He aquí una de las dos versiones, muy resumidas, que anotó Gonzalo Correas en su Vocabulario de refranes de 1627:

Mi marido fue a la mar, chirlos mirlos fue a buscar, para mí, que no tengo mal: ¡echá y bebamos!

8 Véase además, sobre la broma de enviar a alguien a algún lugar lejano, inaccesible o inexistente, para que traiga algo imposible, Pedrosa (2013b). 
Fingiose mala y que no podía sanar sino con los chirlos mirlos de la mar, y persuadió al marido que fuese por ellos, para tener ella tiempo de admitir al cura, y al mejor cenar y beber, el marido dio sobre ellos (Correas 2000: n. $\left.{ }^{\circ} 962,521-522\right)^{9}$.

\section{LAS UVAS INVERNALES DE LOS TRES FAUSTOS CANÓNICOS: 1587 (FAUSTBUCH), 1592 (MARLOWE) y 1808 (GoETHE)}

Entre burlas y veras preparatorias (cuentos maravillosos, epopeyas, milagros, mitos y chistes), llegamos al punto central de nuestra argumentación: a una de las escenas más celebradas del rudimentario y fascinante Fausto que anduvo circulando por la Alemania de finales del siglo XVI (y de después), vertido en un librito popular que llevó el título de Historia von D. Johann Fausten (1587), conocido también como Fausto de Spies (en honor de su editor, el librero Johann Spies de Fráncfort), o Volksbuch vom Dr. Faustus, o Faustbuch simplemente. La tal escena comparte un guion argumental parecido al de los relatos italiano y español que acabamos de conocer: no faltan en ella los frutos de fuera de temporada, ni la dama casada que formula una exigencia de satisfacción presuntamente imposible, ni el galán que se pone a su servicio (ahora será un Fausto que no busca la correspondencia amorosa, sino cumplimentar simplemente a ella y a su aristocrático esposo), ni el auxiliar mágico (aquí Mefistófeles).

Las analogías saltan a la vista en cuanto nos asomamos a la escena 44 del librito alemán:

Sobre las aventuras del doctor Fausto en la corte del principe de Anhalt.

Llegó en cierta ocasión el doctor Fausto a la corte del conde de Anhalt (actualmente son príncipes), quien lo colmó de gracias y favores. Aquello ocurrió un mes de enero.

En la mesa, Fausto advirtió que la condesa estaba en meses mayores. Cuando terminó la cena y sirvieron los postres, el doctor Fausto dijo a la condesa:

-Dignísima señora, como siempre he oído decir que las mujeres encinta tienen deseos y antojos de muy diversas cosas, ruego a V. E. tenga a bien no ocultarme qué le apetecería comer.

Y ella le respondió:

- Señor doctor, la verdad es que no quisiera ocultároslo: me apetecería que fuera otoño y poder comer uvas y fruta fresca hasta saciarme.

A lo cual replicó el doctor Fausto:

—Dignísima Señora, no me será nada difícil complaceros. En media hora será satisfecho el deseo de V. E.

Y cogiendo seguidamente dos fuentes de plata las puso fuera, ante la ventana. Así que hubo transcurrido la media hora, sacó las manos fuera y volvió a meter las

$\overline{9} \quad$ Hay otra versión, algo más breve, en n. ${ }^{\circ}$ 965, 522. 
fuentes: en una de ellas había uvas blancas y coloradas, y en la otra, manzanas y peras, aunque de especies exóticas y provenientes de tierras muy lejanas.

Y mostrándoselas a la condesa, le dijo:

-No tenga V. E. reparo alguno en comerlas, pues vienen de tierras exóticas y muy remotas, donde el verano está a punto de acabar.

Admiróse mucho la condesa y comió de todas las frutas con gran contento. Y el príncipe de Anhalt no pudo por menos de preguntar qué uvas y frutas eran aquellas y cómo las había conseguido.

Y el doctor Fausto le respondió:

-Dignísimo Señor, ha de saber V. E. que el año se divide según los dos hemisferios de la Tierra, y que cuando aquí es invierno, como ahora, en Oriente y Occidente es verano. Pues el cielo es redondo y el Sol se encuentra ahora en su punto más alto, por lo que aquí tenemos los días más cortos y el invierno [...] Sabiendo esto, dignísimo Señor, envié hacia allí a mi Espíritu, que puede volar rápidamente y transformarse al punto en lo que le plazca; él ha traído estas uvas y frutas.

Con gran admiración escuchó el príncipe todo esto (Anónimo del siglo XVI 1994: n. $\left.{ }^{\circ} 44,147-148\right)$.

El plan argumental de esta escena del Faustbuch popular que circuló por Alemania desde finales del siglo XVI es muy parecido a un episodio del drama The Tragical History of the Life and Death of Doctor Faustus (1592) de Christopher Marlowe, quien se inspiraría no solo en algunas de las versiones y traducciones del librito popular que corrieron por ahí, sino también en las tradiciones orales paralelas, conexas o cruzadas que debían de estar flotando en el ambiente (Marlowe 1984: 151-152). No reproduzco el episodio de Marlowe porque difiere no demasiado de la lección del Faustbuch.

Hubiera sido una experiencia fascinante poder cotejar las versiones del Faustbuch (1587) y de Marlowe (1592) con la reescritura de esa misma escena que hubiéramos esperado y deseado que hiciera el genial Goethe más de doscientos años después. Pero Goethe, quien procuró poner distancias con respecto al rudimentario Faustbuch de 1587, que tenía por un precedente elemental y falto de mérito, prefirió, como hizo en tantas otras ocasiones, salirse por la tangente, huir de modelos acuñados y edificar, en la Primera parte (1808) de su Fausto, una trama que muy poco tenía que ver con la más trillada.

Pese a ello, todo lo hizo girar, para no perder el referente, en torno a unas uvas de fuera de tiempo y lugar, mágicamente suministradas por el servicial Mefistófeles: un guiño y al mismo tiempo una traición, por los cambios que introdujo, a la célebre escena de las uvas del Faustbuch y de la tradición oral consuetudinaria en la que debía de estar arraigada. El escenario goethiano fue una taberna en la que saltó la chispa de una pelea entre Mefistófeles y una partida de ruidosos borrachines. Para burlarlos, el diablo urdió la ilusión del traslado de todos ellos a un jardín encantado, con viñedos y uvas rozagantes al alcance de la mano, en el que 
los ilusos persistieron en su pelea hasta que el diablo les quitó la venda de los ojos y los devolvió a la dura y prosaica realidad. Sin las uvas, naturalmente (Goethe 1987: 168-169).

\section{Gagüino CAtón,}

el Fausto español de 1528 y 1529

¿Circuló, cundió, cuajó la leyenda de Fausto, aunque fuese con nombres postizos, en España? Es esa una pregunta que han puesto sobre la mesa no pocos especialistas, desde la orilla casi siempre de la cultura y de las letras canónicas. Su respuesta ha sido confortablemente positiva, porque el tópico del pacto con el diablo para que coopere en el alivio de las ansias de amor, de conocimiento o de riquezas gozó de cierta fortuna en la tradición letrada española, y muchos estudiosos han querido encontrar en esos diseños resonancias fáusticas; y porque la influencia directa sobre los escritores españoles, a partir de Goethe sobre todo, ha sido, por otro lado, incuestionable a partir de la era romántica ${ }^{10}$.

Desde la orilla de la tradición oral y popular, que es la matriz de la que todo surgió y el medio ambiente en que todo se desenvolvió, la respuesta es también positiva, aunque hay que asumir que la cuestión sigue y seguirá estando siempre irresuelta. Primero porque la literatura de tradición oral es la esencia misma de lo efímero, y o bien se esfuma sin dejar huellas de su paso, o bien deja trazas escritas escasas y leves, por lo general fragmentadas, elípticas, confusas, que es difícil localizar, conjuntar y ordenar para que del resultado pueda deducirse un diagnóstico coherente.

Debió de haber, en mi opinión, muchas, innumerables leyendas con elementos fáusticos circulando oralmente por España y por Europa, desde la Edad Media, asociadas a personajes, nombres y lugares que estarían en proceso continuo de mutación y reciclaje. Creo que los tres núcleos narrativos más estables, en torno a los cuales orbitarían escenas y anécdotas más adventicias, serían:

1. el episodio del pacto del sabio con el diablo;

2. el episodio del convite maravilloso a una dama, un matrimonio noble o una autoridad, con un menú de fuera de temporada suministrado con urgencia por un diablo servicial;

3. el episodio de la muerte horrible a manos del diablo, pese a que el protagonista estaba dando pasos para arrepentirse de sus pecados y redimirse.

\footnotetext{
10 Véase, por ejemplo, Méndez (2000) y Hernández (2011). Muy originales y valiosas, porque se hacen tanto desde la orilla de la historia de la magia como desde la orilla de la historia de la literatura, son las averiguaciones de Delpech (1991, 1998 y 2002).
} 
Ni que decir tiene que el episodio $1 .^{\circ}$ lo podemos identificar con el nudo, el $2 .^{\circ}$ con la apoteosis y el $3 .^{\circ}$ con la crisis trágica del personaje. Y huelga recalcar que este ensayo lo estamos dedicando al análisis del episodio segundo.

Es el momento, tras hacer estas apreciaciones, de leer dos leyendas (o dos versiones de una misma leyenda, más bien) de apoteosis: las que puso por escrito fray Antonio de Guevara en los inicios del siglo Xvi; la primera en su Libro áureo de Marco Aurelio, que lleva la fecha de 1528, y la segunda en su Reloj de príncipes, de entre 1529 y 1531 :

Por çierto Gagüino Catón, del antiguo linaje de los Catones, fue en Roma flamen dialis çinco vezes, pretor tres, çensor dos, dictador uno, cónsul çinco vezes; como huviese sesenta y çinco años (passado el año climatérico) diose a servir a Rosana, hija de Gneo Curçio, dama por çierto moça y hermosa. Cresçióle tanto el amor y perdió tanto el sentido, que gastava quanto tenía en servirla y llorava como niño por verla. Acontesçió a la dama darle unas calenturas con hastío, y como dixese que comería de unas uvas y fuese tan temprano que en Roma no eran maduras, embió al Danubio por ellas a parte que avía más de mill millas; y como la cosa fuese sabida en Roma, y de la liviandad se diese notiçia en el Senado, mandaron los Padres Conscriptos que Rosana fuese con las vírgines vestales ençerrada y el viejo perpetuamente de Roma desterrado, y assí los hijos bivieron pobres y el padre murió infame.

Bien creo yo que, oýdo esto, avrá muchos que afeen el hecho del viejo enamorado y loen la sentençia del Senado. Pero también pienso que, si tantos moços tuviese Gagüino en su destierro como terná viejos enamorados imitadores de su exemplo, que no avría tantos hombres perdidos ni mugeres mal casadas. Pues lo mejor de esto es que los tales, quando son avisados de sus criados, reprehendidos de sus parientes y rogados de sus amigos, toman por escusa que son sino enamorados de burla (Guevara, 1994a).

El muy famoso Gagüyno Catón, que descendía del antiguo linaje de los sabios Catones, fue en Roma flamen dialis cinco años, pretor tres, censor dos, dictador uno, cónsul cinco vezes. Siendo de edad de sessenta y cinco años, diose a seguir, y a servir, y a requerir a Rosana, hija de Gneo Curcio, dama por cierto harto moça y no poco hermosa, y assaz de muchos desseada y festejada. Andando, pues, el tiempo, y el dios Cupido haziendo su oficio, encarnó tanto el amor en el coraçón del triste viejo, a que quasi vino a perder el sentido, en que después de aver consumido toda su fazienda en servirla, todo el día sospirava y toda la noche llorava no más de por verla. Acontesció que devieran dar a la dama Rosana unas enojosas calenturas, con gran hastío de no poder comer; y, como se le antojassen unas uvas, y por ser temprano aún en Roma no eran maduras, sabido esto por Gagüino Catón, embió al río Rin por ellas, a parte que avía gran suma de millas. Como la cosa fuesse divulgada por Italia, y en Roma lo supiesse ya todo el pueblo, y de la liviandad se diesse noticia al Senado, mandaron los Padres Conscriptos que Rosana fuesse 
con las vírgines vestales en el templo encerrada y el viejo perpetuamente de Roma desterrado; porque a ellos fuesse castigo y a los otros exemplo.

De verdad que me hizo gran lástima verlo, y aun agora tengo no pequeña pena en escrevirlo, porque vi al padre morir con infamia y a los fijos vivir con pobreza. Bien creo yo que todos los que este exemplo oyeren y todos los que esta escriptura leyeren afearán el hecho del viejo enamorado y aprovarán por buena la sentencia que contra él dio el Senado; pero yo juro que si tantos moços tuviesse Gagüyno Catón en su destierro como terná viejos enamorados que sigan su exemplo, no avría en Roma tantos hombres perdidos, ni mugeres mal casadas (Guevara, 1994b).

No sabemos de dónde le llegaría a Guevara la inspiración para reescribir estos relatos: me ha sido imposible localizar, por el momento, al «Gagüino Catón» (¿Gabino? ¿Gabinius?) al que alude, ni encontrar ninguna fuente escrita consistente o confirmada de la anécdota. Es sabido que de Catón «el Viejo» se dijo y escribió (quien con más detalle lo hizo fue Plutarco, en su Vida de Marco Catón, XXIV) que, viudo y anciano, se casó con una esclava joven y hermosa, a la que algunos llamaron Salonia, no Rosana (Plutarco no dio el nombre, pero a su padre lo identificó como Salonio), y que eso le granjeó conflictos familiares y descrédito social. Pero no sabemos si sería de alguna historia romana de donde saldría el hilo de la anécdota del viejo y enamorado «Gagüino Catón». Tampoco sabemos de qué modo habría podido distorsionar la información recibida el propio Guevara, según era su afición. Por otro lado, y aunque Guevara se hubiese inspirado en algún modelo escrito, es presumible que relatos de esa cuerda anduvieran flotando libremente, reciclados y reencarnados en muchos casos y sujetos antiguos y modernos, en el medio oral de la época, y convidando, por supuesto, a la reelaboración y contaminación.

El que la primera versión de Guevara afirme que el enamorado «Gagüino Catón» envió (no dice a quién, pero un viaje de ida y vuelta con esas urgencias no entraba dentro de las comunes capacidades humanas) por las uvas anheladas al Danubio, mientras que el segundo texto encaminaba al prodigioso emisario al Rin, parece síntoma de fuentes plurales e inestables, de apelación descuidada a la memoria y de interferencias de oralidad.

Pese a que ningún estudioso ha reparado, al parecer, en estas leyendas como hitos de la difusión temprana en España de la leyenda fáustica, su incorporación al dosier que estamos intentando acotar proporciona enseñanzas singulares, ya que no solo enlazan con claridad irrebatible con el episodio de las uvas invernales que era casi emblemático de los Faustos europeos tenidos por primigenios (el Fausto alemán de 1587 y el Fausto inglés de 1592), sino que se adelantan a ellos en unos sesenta años, lo cual no es poca cosa. 


\section{El ¿PRodigio? De Las frutas InTEMPESTIVAS DE LAS Indias}

No mucho después de que fray Antonio de Guevara pusiese por escrito los dos tempranos y excepcionales textos con resabios fáusticos que acabamos de leer, Gonzalo Fernández de Oviedo incorporó estas apreciaciones, interesantísimas por muchas razones, a la gran Historia indiana en la que estuvo trabajando entre 1535 y 1557 :

Y llegaron a esta cibdad de Sancto Domingo poco antes de Pascua de Navidad del año de mill e quinientos e diez y seis años, e aposentáronse en el monesterio de Sanct Francisco. Y notaron mucho que, estando en maitines con los frailes franciscos la noche de Navidad, hobieron tanto calor que sudaron. Y aquel día, a comer les dieron los frailes uvas frescas y higos acabados de coger de las parras y higueras; las cuales fructas y calor son acá comúnmente en tal tiempo; cosa jamás oída ni vista en los reinos de España ni en todo Europa.

Aunque se lee (según dice el maestro Olchod en la glosa que hizo sobre la Esphera), que teniendo un sancto varón en Inglaterra un demonio apremiado en cierta clausura, y deseando el demonio verse libre de aquella prisión, prometió a aquel sancto hombre, la noche de Navidad, de le traer higos frescos de las Indias si le libertase de aquel encerramiento en que estaba; e así, con esta condición libertado, el demonio, en muy breve espacio de tiempo, le trujo los higos frescos que le prometió.

De lo cual aquel sancto varón quedó muy maravillado, conjecturando la grand templanza de tiempo que habría donde se había cogido tal fructa, con la diferencia e rigor del frí que en el mismo tiempo era en Inglaterra, donde era natural creyendo que tierra tan templada y en tal tiempo era muy propincua y cercana al Paraíso Terrenal. Pero no creo yo que los higos serían destas nuestras Indias, porque no los hobo en ellas hasta que de España se trujeron las higueras; uvas bien podría ser, porque así en esta isla como en otras, y en la Tierra Firme, son naturales (Fernández de Oviedo 1992: I, 94).

Estos tres párrafos tan disímiles pero tan equilibradamente engarzados (el primero da cuenta de un episodio histórico, el segundo de una ficción, y el tercero es una exégesis personal, atravesada de ironía) componen, en el orden exacto en que son presentados, una cadena discursiva que ilustra muy bien un modo nuevo, ya plenamente renacentista, de poner en relación las evocaciones del pasado histórico ejemplar y cercano (el año 1516 estaba todavía reciente) y los relatos de magia cuya semilla se perdía entre las sombras de lo medieval inmemorial. Se nos revela por lo demás, en esta cuidadosa secuencia-contraposición de párrafos, un capítulo más de la pugna entre las «verdaderas» y respetables fábulas apólogas (de historia) y las mentirosas y deleznables fábulas milesias (de magias y maravillas), si nos atenemos a la expresión con términos que fueron comunes entre los teóricos de la época. 
Cuando Fernández de Oviedo objetó que los higos que se decía que el diablo había llevado a la Inglaterra medieval era imposible que fuesen de las Indias, puesto que los españoles no habían llevado todavía allí las higueras, no solo estaba tirando de racionalidad y al mismo tiempo de sarcasmo, ya que él era intelectual que no daba crédito a los relatos de magia y diablerías. Estaba jactándose de ser un hombre liberado de las sombras de la superstición y del embrujo del cuento de magia que (para él sí, pero no para la mayoría) se habían quedado tras el antes y el después que había supuesto la llegada a América; igual que se mostraba orgulloso de ser un historiador provisto de una ciencia nueva, que se sabía superior a la especulación mágica de la Edad Media.

Por más que, como testigo y cronista de la cultura y de los discursos de su tiempo, tuviese la obligación de dejar constancia del asombro que los españoles de 1516 habían experimentado ante la revelación de lo nunca visto (aunque sí muchas veces oído, en los relatos de magia) en España, que era un país en el que nadie había tenido la experiencia, todavía, de las uvas frescas (que se cosechan en el otoño) ni de los higos frescos (que se cosechan en el verano) en el tiempo de la Navidad.

Impresiona (permítaseme el excurso) el casi exacto antagonismo de la trama de ese relato protagonizado por el taumaturgo inglés y por su auxiliar diabólico que aflora al comparar con este otro relato, publicado en 1594 (aunque de ancestros muy viejos) acerca de la mártir santa Dorotea, de la que se decía que había enviado a un auxiliar angélico a buscar rosas y manzanas de febrero a «las Indias Occidentales, donde a la sazón era verano y tiempo de rosas y frutas», para que fuesen entregadas, con el fin de que certificasen su santidad, a un sujeto que había hecho burla de su sacrificio.

Frutas intempestivas traídas desde las nuevas Indias e injertadas en un exemplum de tono y raíz medieval. Y por un ángel, no por un demonio de los que de forma común se hacían cargo de aquellos portes: ¿qué no hubiera elucubrado al respecto el inquisitivo Fernández de Oviedo?:

Llevando a degollar por la Fe de Cristo a santa Dorotea, passó cerca de donde estava un letrado jurista llamado Teófilo. El cual, aviéndole oído dezir, cuando estava en presencia del tirano que la martirizó, que en todo tiempo avía rosas y mançanas adonde Jesucristo estava y ella dezía que iva, díxole por irrisión y haziendo burla:

-Ea, donzella, hazednos gracia que cuando estéis en la tierra de vuestro Esposo nos embiéis de allá algunas rosas y manzanas.

Esto era en seis de febrero, cuando ni mançanas ni rosas se hallan, y por esto hizo semejante demanda, como para burlarse della. Dorotea respondió que haría lo que le dezía.

Llegó al lugar donde la avía de degollar; pidió que la dexassen hazer oración brevemente. Concediósele, y, hecha, apareció delante della un niño hermosissimo 
con un canastico, y en él tres rosas y tres mançanas hermosíssimas, traídas por él, que sería ángel, en tiempo brevíssimo, de alguna parte de la tierra, como de las Indias Occidentales, donde a la sazón era verano y tiempo de rosas y frutas. Díxole la santa:

-Ve a Teófilo y dile de mi parte que ai van rosas y mançanas.

Fue la santa degollada y boló su alma al Cielo.

Estava Teófilo después desto haziendo donaire de lo que con Dorotea le avía passado, contándolo a otros oficiales del Presidente. Llegó a él el niño hermoso y trabóle de la capa, como que le quería hablar aparte. Él bolvió y, viéndole tan hermoso, y admirado de oír sus razones tan concertadas, estuvo atento a ellas. Oyóle dezir que Dorotea le embiava aquel regalo de mançanas y rosas. Recibiólas Teófilo y desapareció el niño, por lo cual él se convirtió a la Fe, y fue martirizado. Dízelo San Isidoro en el Himno del Oficio desta santa (Villegas 1988: ff. 179v-180r) ${ }^{11}$.

La estupefacción que causaban las frutas americanas intempestivas no fue Fernández de Oviedo el único que la documentó. Sabemos, de hecho, que en la $R e$ lación de Colón del viaje a Cuba y Jamaica (1495) había quedado ya, y no por casualidad, el apunte de que «en Çibao en aquel tiempo, que era mediado março, hallé uvas maduras de muy buen sabor»; en otro párrafo se decía que «viña ya fallamos harta, y aunque no se labrava, dava el razimo muy grande y los granos gordos, de la cual comí en quinze de março maduros» (Colón 1992: 290 y 283). Entre 1527 y 1550 anotó fray Bartolomé de las Casas acerca de unas tierras de Venezuela en las que estuvo, que «dos veces se siembra y coge el grano y otras muchas cosas cuasi cada mes y fructas cuasi todo el año, y en tierra firme, a la parte de Cumaná, he comido yo dos veces uvas de las nuestras de Castilla en obra de cinco o seis meses, todas de unas mismas vides o parras» (Casas 1988-1998, 1992: 378).

Comer uvas en el mes de marzo o gozar de dos cosechas de uvas en el año eran hipótesis que, puesto que aquellos fugaces frutos indianos no podían resistir, por lo general, la prueba del viaje a España, solo podían llegar de oídas y caber en los sueños más extraviados de los peninsulares de la época. Gentes que, en su gran mayoría, tenían la experiencia del duro trabajo y del inflexible calendario del campo y que, desde el primer regreso de Colón, habían quedado sometidas al bombardeo de noticias, aprobadas y bendecidas por autoridades supuestamente

11 Las rosas y otras flores a destiempo, con sus olores, son elementos más o menos recurrentes en otras vidas de santos. Así, en una Vida de santa Cecilia de la que sabemos gracias a Cortés Guadarrama (2010: 712), se habla de la conversión de Tiburcio en estos términos: «después desto, entrando Tiburcio, hermano de Valeriano, e sentiendo muy grant oler de rosas, dixo: - Maravíllome onde vino este olor de rosas e de lirios en este tienpo. Ca si yo toviese esas rosas o lirios en las mis manos, sabría si darían tan grant olor, e sabed que só demudado. Dixo Valeriano: —Nós tenemos coronas que non pueden ver tus ojos, e son guarnecidas de flores e de blancos colores. E ansí commo yo fablando sientes el olor, ansí las podrás ver si quisieres creer». 
acreditadas, acerca de frutos intempestivos y monstruosos, contrarios a su experiencia del clima, que venían a solaparse con los frutos también intempestivos, y con intenso tufo demoníaco, muchas veces fáustico, de los viejos relatos de magia que bullían en su impresionable imaginario.

Mundos diferentes (el de la historia y la magia-maravilla) y tradiciones literarias diferentes (la de la noticia y la del cuento folclórico) que entraron en colisión, en fin, en un tiempo, el renacentista, en que las crisis y conflictos entre realidades y hermenéuticas dejaron su poso en todos los ámbitos de la vida. Todas aquellas novedades se presentaban, de hecho, como una escalada de anomalías que al poner a prueba los fundamentos del calendario y el devenir de las estaciones, afectaba también a la cultura común, a los cimientos del mundo... y a las modalidades del relato. También, y no solo en España sino en Europa entera, a otras parcelas de la cultura, como la pintura, la arquitectura, la decoración: quien, por ejemplo, contemple las frutas quiméricas y extravagantes y las caras y bocas de estupefacción y codicia que, a la zaga de tales frutas, pueblan las pinturas del Bosco (ca. 1450-1516), podrá apreciar desde el ángulo de las representaciones visuales los extravagantes efectos que aquellas novedades causaban.

\section{La transustanciación en milagro: Las Rosas de GuadaluPe (1531) Y LOS Higos QUE SOLo Dios PUEDE ADELANTAR o RETRASAR (1607)}

El cotejo del exemplum cristiano de santa Dorotea que hemos conocido páginas atrás, por el que se paseaba aquel

niño hermosíssimo con un canastico, y en él tres rosas y tres mançanas hermosíssimas, traídas por él, que sería ángel, en tiempo brevíssimo, de alguna parte de la tierra, como de las Indias Occidentales, donde a la sazón era verano y tiempo de rosas y frutas

con el relato acerca del

sancto varón en Inglaterra [que tenía] un demonio apremiado en cierta clausura, y deseando el demonio verse libre de aquella prisión, prometió a aquel sancto hombre, la noche de Navidad, de le traer higos frescos de las Indias si le libertase de aquel encerramiento en que estaba; e así, con esta condición libertado, el demonio, en muy breve espacio de tiempo, le trujo los higos frescos que le prometió

no puede menos que llamar a reflexión acerca de las conexiones que pueden ser establecidas entre el discurso de la religión y el de la magia, y entre el género de los relatos de maravillas y de los relatos de milagros. Pero una profundización sistemática requeriría, por su complejidad y trascendencia (y porque se 
inmiscuirían los géneros del cuento oral y del cuento literario, de la denuncia de la brujería y los tratados de esoterismo, de las crónicas de Indias y de los libros de viajes, etc.), un espacio, un tiempo y un esfuerzo de análisis que no nos están permitidos ahora.

Máxime cuando las complicidades fehacientes que hay entre el cuento de santa Dorotea y el del cura-mago inglés, que dan hasta la impresión de ser cuidadosamente simétricos, se inscriben dentro de un círculo que se solapa con otros círculos por los que, de modo más irregular y aleatorio, orbitan enanitos que desde tierras muy lejanas aportan rosas, culebritas que traen higos, viejecitas que traen brevas, y toda una caterva de pintorescos transportistas que se enfundan hábitos de nigromantes, diablos, Mefistófeles y camareros fantasmales, a los que se irán sumando, en páginas que están por llegar, familiares proveedores de frutas intempestivas de Valencia o estudiantes equívocos que regalan peras prodigiosas en Burgos.

Mejor concentrarnos ahora en la constatación de que el milagro presuntamente obrado en el mundo hispánico durante la Edad Moderna que más discursos, exégesis, iconografías, alegorías, ritualidades, devociones públicas y privadas, peregrinaciones, movimientos de masas y presuntos milagros subsidiarios ha suscitado o movilizado es, sin duda, el que se halla simbolizado por las «flores de Castilla» o «rosas de Castilla» o simplemente «rosas» (los testimonios y tradiciones difieren) que se dice que en el mes de diciembre de 1531 el indio chichimeca Juan Diego Cuauhtlatoatzin encontró en el cerro de Tepeyac de la Ciudad de México y cortó y llevó al obispo Juan de Zumárraga, en señal de que la Virgen le enviaba con el encargo de que en el lugar fuese erigido el templo de Guadalupe.

No diré más, ahora, acerca de aquel milagro mariano, sobre el que la bibliografía es colosal, aunque no pasaré por alto señalar que la asociación de las rosas invernales con la Virgen (y no solo con la de Guadalupe) llegó a pasar, en no pocas ocasiones, del plano metonímico al metafórico. Estos versos de 1604 dan fe de ello:

\section{Parece la hermosísima doncella entre el hielo y la nieve rigurosa como entre nubes matutina estrella o en medio del invierno fresca rosa}

(Valdivielso 1854: 190).

Tampoco me extenderé aquí acerca de los demás célebres milagros de rosas intempestivas (de santa Isabel de Hungría, santa Isabel de Portugal, santa Casilda de Toledo, san Diego de Alcalá y muchos más) que han sido puestos en relación con el milagro de las rosas de Guadalupe.

Solo añadiré que algún comentarista hubo que en torno a 1607, en tanto que exaltaba a Dios como demiurgo de espacios y de tiempos, de tierras y de estaciones, 
volvía a echar mano del muy manido tropo de los higos frescos cuando no era su estación. No se trata de un texto menor, porque en tanto que concentra en la figura de Dios la potestad de acelerar o de retrasar la cosecha de los higos está refutando, implícitamente, todas las magias demoníacas, los cuentos maravillosos, las crónicas de viajes que atribuían a otros sujetos o causas aquella jurisdicción:

Él es el que maldijo a la higuera porque no tenía fructa, no obstante, como notan los sanctos, sin ser tiempo de higos, porque basta querer Dios para que, cuando él gustare, sea primavera y otoño y aceleren el paso en el dar su fructo, aunque sea en medio de las heladas del invierno (Concepción 1998-2002: II, 484).

\section{Un Fausto de El Viso (Toledo) de 1575-1580,} UNO BURGALÉS DEL SIGLO XVIII Y OTRO VASCO DEL XX

Un texto de gran relevancia y que ha pasado muy desapercibido hasta hoy, pese a la posición destacada que ocupa en el panorama de la desdibujada leyenda fáustica española, es el que, a propósito de Hernando Alonso, un cura-mago-taumaturgo-embaucador que se decía que había vivido en tiempos pasados (se supone que hacia finales del siglo xv) en el pueblo toledano de El Viso de San Juan, quedó incorporado a las Relaciones topográficas que entre 1575-1580 fueron cumplimentadas en los pueblos del antiguo Reino de Toledo.

El cura taumatúrgico en cuestión o, mejor dicho, su recuerdo fabulado y mitificado, es el centro de unas cuantas páginas cuyo desusado escrúpulo en lo que se refiere a anotación y justificación de fuentes conoce muy pocos parangones en la documentación de aquellos siglos. El informe acerca de él está firmado, de hecho, por quien debió de ser sucesor suyo en el lugar, el locuaz y expresivo «Pedro Alonso Castrovid, cura propio de la dicha villa» de El Viso, quien no conoció al mago en persona, por lo que hubo de informarse entre los más mayores, que tampoco hay garantías de que lo hubiesen conocido: «esto oi yo [...] a personas fidedignas y viejas que acontecio ansi».

En las páginas previas del mismo informe se había explayado Castrovid acerca de las disparatadas andanzas que se recordaban de otro clérigo taumaturgo y amigo de Alonso, y gracias a eso podemos allegar algún dato y alguna fecha más, que situaría a los dos en los finales del siglo xv, si es que no era todo puro cuento:

En esta villa y tierra hubo habra ochenta años mas o menos, dos hombres señalados en letras de nigromancia, el uno clerigo, cura que fue de la dicha villa, el otro fraile de una orden que se llamaba Santi Espiritus simondal (?). De estos, el uno se decia el doctor de las Moralejas y el otro Hernando Alonso, cura susodicho. 
El caso es que las averiguaciones que nos comunicó Castrovid acerca de Alonso, pese a que se hallan más escoradas hacia el lado de la leyenda que hacia el de la historia, son sensacionales:

Hernan[d]o Alonso, cura susodicho que fue de esta villa, fue tambien persona señalada en esta dicha ciencia de nigromancia porque se dice de el que despues que al dicho doctor de las Moralejas, su amigo y compañero, le habian llevado mortecido a la villa de Cedillo, cuando le sacaron de la dicha cueva, que es en esta villa, do dicen Las Pozas, que el dicho cura consulto con sus familiares que tinie puestos en siete calaveras de hombres con siete lenguas de palio colorado, en cada una calavera, su lengua, atapadas las calaveras con cera bendita, y hechos sus artificios de manera que parecian cabezas de hombres sin carne, y haciendo sus conjuros el dicho cura y hablaban todas las calaveras como si fuesen hombres y este dicho cura se halla por relacion que en mucho tiempo no dixo misa y muchas veces de caeçie [sic: lo correcto debe de ser "acaeçie"] el dia de Navidad sacar a los altares dos redomas llenas de clavellinas tan verdes, tan hermosas, tan frescas como si se cogieran por el mes de mayo.

Tinie mas este dicho cura que en dias de Pascua y visperas le decian sus amigos o devotos o conoscidos que les diesen colacion, dicie que esperasen un poco que venian sus criados, que entonces les daria colacion, y el en espacio de una hora enviaba se presume un familiar que traie de todas las fructas de Valencia y esto de sus cercos y conjuros uno de los espaldares de la iglesia de la dicha villa de El Viso, adonde se demuestra agora donde criaba las serpientes ponzoñosas para hacer sus maleficios, y habra cinco o seis años que se derribaron las alhacenas donde estaban las calaveras de los familiares.

Bien se pudiera decir de este cuentos algo lascivos y sucios que hizo con su nigromancia $[\ldots]$.

Y esto oi yo, Pedro Alonso Castrovid, cura propio de la dicha villa, a personas fidedignas y viejas que acontecio ansi.

Murio este dicho cura, y fue causa de su muerte la dicha cueva que se le aparescio al labrador, de donde llevaron amortecido a su amigo y compañero el doctor de las Moralejas, porque el dicho cura hizo un acetre y caldero con ciertos signos y caracteres que llevaba en el, y sacando agua de la dicha cueva con el se resfrio y murio, y hizo nacer una capellania de su hacienda perpetua que esta en la iglesia de la dicha villa hoy dia al presente (1951-1963: III, 774-776).

Impresionante el retrato del cura Hernando Alonso, de El Viso de Toledo, que en la Navidad no prescindía del adorno de clavellinas frescas como las de mayo, y que en Pascua se podía permitir el lujo de convidar a sus amistades a frutas que sus serviciales «criados» (cuyo tufo demoníaco no debía de ser fácil disimular) eran capaces de despachar, en tan solo una hora, desde Valencia.

Su calidad es notoria, y su rareza notable, o más que notable. No solo por los méritos extrañísimos del testimonio, que tienen conexión sin duda con la leyenda 
fáustica, sino porque se trata además del único paralelo documentado en España, creo, de una tipología de relatos a la que espero poder prestar atención en alguna ocasión futura. Adelantaré que su versión más conocida es la que sintetizaron (a partir de fuentes antiguas) los hermanos Grimm en la que hace el n. ${ }^{\circ} 495$ (Albertus Magnus und Kaiser Wilhelm) de sus Deutsche Sagen, Leyendas alemanas (18161818). Quien ofició de anfitrión y taumaturgo según cuenta aquella tradición fue nada menos que san Alberto «el Grande» (1200-1280), científico y teólogo alemán que fue maestro de santo Tomás de Aquino. De él se contaba que, habiendo convidado a comer al conde de Holanda, Guillermo II, a su convento, no se le ocurrió otra cosa sino disponer la mesa al aire libre, cuando era pleno invierno. Ahora bien: en cuanto el duque y los suyos se sentaron, el invierno se trocó en primavera, y los manjares servidos fueron, por supuesto, lujosos y de fuera de temporada.

Es el momento ahora de prestar atención a otro pariente español y completamente ignoto de Fausto, cuya noticia nos ha llegado como narración suelta, con pintorescos versos interpolados, en un desatendido manuscrito del siglo XVIII. Es muy posible, creo, que tal versión sea copia de algún documento de fecha anterior, y no me extrañaría que la época de composición pudiera remontar al XvII. Admira que el diablo-estudiante-licenciado auxiliar (la figura del estudiante con resabios diabólicos cuenta con una más que interesante tradición en España), en el momento en que entrega a su señor las peras, «por el tiempo que no había peras», le ofrende una ingeniosa décima (Delpech 1991).

Eso le convierte en el primer diablo-licenciado-poeta, al tiempo que proveedor mágico de fruta, del que tenemos noticia:

Dixeron a un Arzobispo de Burgos, que a un licenciado, a quien quería dar un beneficio, era tonto, no siéndolo. Súpolo el licenciado, y por el tiempo que no había peras, buscándolas, y presentándoselas al arzobispo, y dándole esta Décima alcanzó el beneficio.

Décima.

No es cosa desesperada

el dar a un príncipe peras, quando espera muy de beras y ya esperado conservada.

Espero vendrá pintada y no es pera doctoral, que es camuesa de un peral, y con esperanza entera, es una pera que espera ser pera pontifical

(ms. 10.912: f. 202). 
Resta todavía por ser llamado a capítulo otro Fausto español: el fantasmal Axular que mantiene una amena conversación, sobre temas esencialmente literarios, con el propio escritor Bernardo Atxaga, en uno de los capítulos de su libro Obabakoak, cuya versión en euskera es de 1988, y cuya versión en castellano, preparada por el propio Atxaga, vio la luz en 1989.

Axular es un trickster o personaje apicarado y taumatúrgico muy asentado en el folclore vasco. De él se habla, según las ocasiones, como bandido, o como estudiante con ribetes de mago, o como cura con poderes... Aunque, antes de ingresar en el dominio de la leyenda, fue una persona de carne y hueso: Pedro de Aguerre y Azpilicueta (1556-1644), alias Pedro de Axular, Axular o Atxular simplemente, cura, teólogo, retórico, filósofo y escritor precursor en lengua vasca.

El poco espacio que le podemos dedicar aquí es para informar de que el narrador del cuento de Atxaga (quien lleva el nombre del mismo Atxaga) sueña un encuentro y una conversación con Axular en una isla desierta, en la que hablan del modo en que las historias se comunican (o plagian y son plagiadas) con las demás historias. En tanto que conversan, Axular pone servicialmente un plato de higos frente a los dos. Cuando su interlocutor desaparece de improviso, Atxaga se queda dando vueltas a todo lo hablado. Hasta que cae en la cuenta:

"¿De dónde han salido estos higos?», me pregunté entonces atónito. Porque todavía no era la temporada de higos en Obaba.

Cogí el plato blanco en las manos, y, al examinarlo, se me disiparon todas las dudas. Pues saltaba a la vista que los frutos que estaban allí tan primorosamente dispuestos eran los mismos que había recogido Axular en la isla (Atxaga 2007: 306).

\section{Todo es nADA: TESOROS DE LOS DUENDES, IMÁGENES DEL BIEN LIMITAdO Y TRÉBOLES DE CUATRO HOJAS}

Hay algo muy arraigado en la condición humana que ayuda a explicar la intemporalidad y la universalidad de los relatos en que una ilusión que se nos antoja singularmente prometedora se nos aparece y al poco se esfuma, por más esfuerzos que hagamos por retenerla: el creerse cerca de las rosas de enero o de los higos o uvas o peras a destiempo (o de algún avatar de su serie) colocaba a cualquier sujeto anónimo a un paso (siempre a un paso) de la liberación de la miseria, del hambre, del dolor inherente a ser humano. El solo atisbo de tales flores y frutos impensables, ya fuesen obra de brujería (de brujería cervantina, por ejemplo), prodigio (de prodigio fáustico, por ejemplo) o milagro (de milagro de Guadalupe, por ejemplo), se creía preámbulo de la redención, señal de privilegio, invitación a comulgar con alimentos del paraíso que habían caído fortuitamente en el jardín 
de acá y que había que darse mucha prisa en acaparar para poder beneficiarse de sus efectos.

Hay, por cierto, otros relatos de vanidades más o menos emparentadas con estas a los que solo podemos aludir superficialmente en estas páginas: en muchos pueblos de la península ibérica (y de otras geografías) era creencia tradicional que, sobre todo en la noche o en la mañana de san Juan, es decir, en el solsticio de verano, se aparecían en lugares silvestres (montes, prados, fuentes, ríos) hadas (o mouras, xanas, encantadas...) que ofrecían a quien se diese prisa en madrugar un peine de oro o algún otro don que nunca acababa de concretarse; o que se manifestaban gallinas de oro con pollitos inquietos que nunca eran capturados; o que se entrometía en el mundo de acá algún otro ser numinoso (que en versiones cristianizadas era la Virgen María) que ofrecía a la doncella que primero llegase a la fuente la enigmática flor del agua, que se tenía por promesa de fecundidad (Pedrosa 2014a; Pedrosa 2015). En Portugal han estado vivas hasta hoy las leyendas acerca de pastores o de rústicos que al atravesar durante el invierno algún territorio agreste encuentran higos frescos dejados allí por alguna moura: los higos se convierten en oro durante el camino del pastor a casa pero, al llegar a la geografía de los humanos, vuelven a metamorfosearse, esta vez en carbón o en excrementos de animales (Parafita 2006: n. ${ }^{\text {os }} 7,8,49,89$ y 202) ${ }^{12}$.

Hubo en el pasado y hay en el presente dos etiquetas, una de cuño coloquial y popular y otra de naturaleza técnica, que servirían para calificar con justeza todo ese elenco de flores, frutos y dones mágicos y fugaces: la de tesoro de los duendes y la de imagen del bien no limitado.

La de tesoro de los duendes fue expresión vulgar que en la España de hace siglos cobró carta de naturaleza y estuvo en boca de muchos para designar todo lo que prometía y que luego no se cumplía, aquello que recordaba el color o el sabor del oro y se ponía al alcance de la mano, pero solo en cuentos o en sueños. Esa expresión con un poso de ironía, claro, y con mordaz escepticismo la utilizó don Quijote cuando se la aplicó a sí mismo y a su oficio: «los tesoros de los caballeros andantes son como los de los duendes, aparentes y falsos» (Cervantes 1998: 1.174). Acerca del sinfín de casos, leyendas y cuentos (orales) que se le asociaban, porque hubo épocas en que pareció que todo el mundo había entrevisto por un momento y narraba su experiencia (truncada) de algún tesoro de los duendes, hizo una disertación pesimista y memorable Sebastián de Covarrubias (2006: s.v. «tesoro de duende»).

La de «imagen del bien no limitado» (image of unlimited good) es expresión nacida de la jerga científica del siglo xx, acuñada por el antropólogo

12 Acerca de las versiones portuguesas de la leyenda, véanse los comentarios de Marques (2011: 85-86). 
norteamericano George M. Foster (1965, 1967). Aunque Foster elaboró sus ideas partiendo de su experiencia de observación de campo de las realidades, los relatos, las ritualidades y los conflictos que pautaban la vida en algunos pueblos remotos de México, ideas y sueños que vienen a coincidir a grandes rasgos con la «imagen del bien no limitado» han tenido encarnaciones (y reencarnaciones y sobre todo «des-encarnaciones») incontables a lo largo de los tiempos: los mitos de la edad de oro y del paraíso, el vellocino de oro, el becerro de oro, el tesoro de los nibelungos, El jardín de las delicias o El carro de heno que pintó el Bosco, la isla de Jauja, el país de Cucaña o de Cockaigne, los jardines de especias de las Indias orientales y occidentales, El dorado, el oro de California o de Alaska, los pozos de petróleo y las minas de diamantes o de uranio, los premios de la lotería o de las apuestas, las ganancias del póker, Wall Street o Silicon Valley, son algunos de sus casi infinitos avatares y escenarios reales o alegóricos.

Las rosas, los higos, las uvas, las peras intempestivas que dan y quitan la fortuna han de tener su hueco en algún pliegue de esa serie, como han de tenerlo también los cuasi prodigiosos (aunque no inexistentes en el medio natural) tréboles de cuatro hojas, que casi todos nosotros, sugestionados por los muchos relatos ilusorios que hasta nuestros oídos llegaban, hemos buscado con ansiedad cuando éramos niños.

La ilusión puede ser una parte de nuestras vidas muy real. El hecho de que en el currículum cultural de todos haya habido años en que el trébol de cuatro hojas nos pareciera una dimensión admisible de la realidad y un accidente que podía influir en nuestros horizontes de vida nos liga de un modo que quizá no esperábamos (como creyentes, aparte de como críticos literarios) a la extravagante comunidad de quienes alguna vez creyeron en las rosas de diciembre de la hechicera cervantina o de la Virgen guadalupana, en las fresas en la nieve del cuento vasco, en las uvas adelantadas a su época de Gagüino Catón (el primer Fausto español y europeo), en las «uvas blancas y coloradas» invernales del Fausto de 1587, o en los frutos indianos que eclosionaban prodigiosamente al margen de la estación que en Europa se consideraba normal. 


\section{BIBLIOGRAFÍA}

ABDELKEFI, Mohamed (2018). En busca del pájaro esmeralda y otros cuentos tunecinos de Lela Ula. Madrid: Mitáforas.

AbDelkefi, Mohamed (2019). La montaña de abanicos y otros cuentos tunecinos de Lela Ula. Madrid: Mitáforas.

Agúndez García, José Luis (1998). «Cuentos populares andaluces (III) (Parte II)». Revista de Folklore, 216, pp. 193-198.

Anónimo del siglo XVI. Historia del doctor Johann Fausto (1994). Juan José del Solar (ed.). Madrid: Siruela.

AtxagA, Bernardo (2007). «Método para plagiar». Obabakoak. Madrid: Alfaguara, pp. 297-311.

Azkue, Resurrección María de (1989). Euskalerriaren Yakintza: Literatura popular del País Vasco. Bilbao/Madrid: Euskaltzaindia/Espasa Calpe.

Boccaccio, Giovanni (1998). Decamerón. María Hernández Esteban (ed.). Madrid: Cátedra.

BonAzzi, Nicola (2014). «Da Dianora a Marietta. Metamorfosi di un'illusione cortese». Heliotropia, 11-12, pp. 121-139.

Borghello, Giampaolo (2001). «La neve e il fuoco. La dinamica dei personaggi nella novella di Madonna Dianora (Decameron, X 5)». En Studi in ricordo di Guido Barbina. II. Est Ovest. Lingue, stili, società. Udine: Forum, pp. 133-158.

Camarena Laucirica, Julio y Maxime Chevalier (1995). Catálogo tipológico del cuento folklórico español. Cuentos maravillosos. Madrid: Gredos.

CASAS, fray Bartolomé de las (1992). «Apologética historia sumaria». En Vidal Abril Castelló, Jesús Ángel Barreda, Berta Ares Queija y Miguel J. Abril Stoffels (eds.), Obras completas. Madrid: Alianza, vol. 6.

Cervantes, Miguel de (1998). Don Quijote de la Mancha. Francisco Rico (ed.). Barcelona: Crítica.

Cervantes, Miguel de (2013). Novelas ejemplares. Jorge García López (ed.). Madrid: Real Academia Española.

Chevalier, Maxime (1979). «De los cuentos populares cubanos a los cuentos folklóricos del Siglo de Oro». En Hommage des hispanistes français a Noel Salomon. Barcelona: Laia, pp. 155-168.

CID, Jesús Antonio (1985). «Peru gurea (EKZ, 115), der Schwank vom alten Hildebrand, y sus paralelos románicos (Aa.-Th., 1360C)». Seminario de Filología Vasca «Julio Urquijo», 19, pp. 289-353.

CID, Jesús Antonio (2011). «Glosas imposibles y malicias trocadas: de las Academias del Barroco a la improvisación oral (...y don Juan Vélez de León)». En Alain Bègue y Antonio Pérez Lasheras (eds.), «Hilaré tu memoria entre las gentes»: Estudios de literatura áurea (en homenaje a Antonio Carreira). Zaragoza: Prensas Universitarias de Zaragoza, II, pp. 159-192.

Colón, Cristóbal (1992). Textos y documentos completos. Consuelo Varela y Juan Gil (eds.). Madrid: Alianza. 
Concepción, san Juan Bautista de la (1998-2002). Obras completas. Juan Pujana, O. SS. T. y Arsenio Llamazares, O. SS. T. (eds.). Madrid: Biblioteca de Autores Cristianos.

CORREAs, Gonzalo (2000). Vocabulario de refranes. Louis Combet (ed.), ed. revisada por Robert Jammes y Maïté Mir-Andreu. Madrid: Castalia.

Cortés Guadarrama, Marcos Ángel (2010). «[CXXXVIII] Título CXXXVII. Disposición de santa Cecilia». El Flos sanctorum con sus ethimologías. Edición y estudio. Oviedo: Universidad de Oviedo, pp. 710-718.

Covarrubias Horozco, Sebastián de (2006). Tesoro de la lengua castellana o española. Ignacio Arellano y Rafael Zafra (eds.). Madrid/Frankfurt am Main: Iberoamericana/Vervuert.

Curiel Merchán, Marciano (1987). Cuentos extremeños. María José Vega (introd.). [Mérida]: Editora Regional de Extremadura.

DELPECH, François (1991). «L'écolier diabolique: aspects ibériques d'un mythe européen». En Jean-Louis Guereña y Ève-Marie Fell (ed.), L’Université en Espagne et en Amérique Latine du Moyen-Âge à nos jours. I, Structures et Acteurs. Tours: Publications de l'Université de Tours, pp. 155-177.

DELPECH, François (1998). «Grimoires et savoirs souterrains. Éléments pour une archéo-mythologie du livre magique». En Dominique de Courcelle (ed.), Le pouvoir des livres à la Renaissance. Paris: École des Chartes, pp. 23-46.

DELPECH, François (2002). «La recherche de la souveraineté perdue. Notes sur quelques fragments d'un Gerbert mythique». Ollodagos, 17, pp. 3-63.

Ercilla, Alonso de (1993). La Araucana, Segunda Parte. Isaías Lerner (ed.). Madrid: Cátedra.

Fernández de Oviedo, Gonzalo (1992). Historia general y natural de las Indias. Juan Pérez de Tudela Bueso (ed.). Madrid: Atlas.

Foster, Georg M. (1965). «Peasant Society and the Image of Limited Good». American Anthropologist, New Series, 67, pp. 293-315.

Foster, Georg M. (1967). Tzintzuntzan: Mexican Peasants in a Changing World. Boston: Little, Brown and Co.

Goethe, Johann Wolfgang von (1987). Fausto. Manuel José González y Miguel Ángel Vega (trads.). Madrid: Cátedra.

Guevara, fray Antonio de (1994a). Libro áureo de Marco Aurelio. Emilio Blanco (ed.). Madrid: Turner.

Guevara, fray Antonio de (1994b). Reloj de príncipes. Emilio Blanco (ed.). Madrid: Turner.

HERnÁNDEZ, Isabel (2011). «Para gozar a esta mujer diera el alma. El mito fáustico y sus rescrituras en la literatura española». Revista de Literatura, 73, pp. 427-448.

Laroche, Béatrice (2003). «L'amour dans les jardins du Décaméron». Chroniques italiennes, $3<\mathrm{http} / /$ chroniquesitaliennes.univ-paris3.fr/PDF/Web3/B_LAROCHE. pdf $>$ [Consulta: 01/08/2019].

LóPEZ, Atanasio (1915). «Antonius Santarenensis de Ordine Minorum». En La provincia de España de los Frailes Menores. Apuntes histórico-críticos sobre los orígenes de la Orden franciscana en España. Santiago: El Eco Franciscano, pp. 353-359. 
Marcus, Millicent (1980). «An Allegory of Two Gardens: The Tale of Madonna Dianora». Forum Italicum, XIV, pp. 162-174.

MARlowe, Christopher (1984). La trágica historia de la vida y muerte del Doctor Fausto. Julio César Santoyo y José Miguel Santamaría (eds.) Madrid: Cátedra.

MARques, José Joaquim Dias (2011). «De boca en boca: o rumor como arma contra os outros (mesa redonda)». En Actas das IV Xornadas de Literatura de Tradición Oral. Lendas urbanas: mitos e ritos dos tempos modernos. Lugo: Asociación de Escritores en Lingua Galega, pp. 83-90.

MÉNDEZ, Sigmund (2000). El mito fáustico en el drama de Calderón. Kassel: Reichenberger.

PABA, Antonina (2013). «El jardín engañoso de María de Zayas: de la novela a la relación de sucesos». En Pedro M. Cátedra García (dir.), María Eugenia Díaz Tena (eds.), Géneros editoriales y relaciones de sucesos en la Edad Moderna. Salamanca: SEMYR, pp. 299-311.

PARAFITA, Alexandre (2006). A mitologia dos Mouros: lendas, mitos, serpentes, tesouros. Canelas: Edições Gailivro.

Paredes Monleón, María Libertad (2014). «La función del demonio en dos novelas de María de Zayas». En Mariela Insúa y Robin Ann Rice (eds.), El diablo y sus secuaces en el Siglo de Oro. Algunas aproximaciones. Pamplona: Servicio de Publicaciones de la Universidad de Navarra, pp. 69-83.

Pedrosa, José Manuel (1995). «Mi marido fue a la mar, chirlos mirlos a buscar: burla y sentido de un chiste cantado en el Siglo de Oro». Iberorromania, 41, pp. 17-27.

Pedrosa, José Manuel (2013). «Lázaro, Sancho, don Pablos, Juan Ramón y otros inocentes burlados: geografías de la risa iniciática». En Mariana Masera (ed.), Mapas del cielo y la tierra: espacio y territorio de la palabra oral. Ciudad de México: Universidad Nacional Autónoma de México, pp. 321-362.

Pedrosa, José Manuel (2014). «El romance de La flor del agua: discursos, motivos y fórmulas». En Carlos Villanueva (ed.), Victor Said Armesto: una vida de romance. Santiago de Compostela: Xunta de Galicia-Consorcio de Santiago-Universidade de Santiago de Compostela, pp. 301-339.

Pedrosa, José Manuel (2015). «La flor del agua, libreto de zarzuela de Víctor Said Armesto: tópicos y metáforas». En Carlos Villanueva, Justo Beramendi, Carlos García Martínez y Margarita Santos Zas (eds.), Victor Said Armesto e o seu tempo: perspectivas críticas. Santiago de Compostela: Fundación Barrié-Museo do Pobo Galego-Diputación de Pontevedra, pp. 239-259.

Pérez-Abadín Barro, Soledad (2006). «La Arcadia y otros modelos literarios del Coloquio de los perros de Cervantes: apuntes sobre magia». Nueva Revista de Filología Hispánica, 54, pp. 57-102.

PÉrez-EMBid Wamba, Javier (2001). Hagiología y Sociedad en la España Medieval. Castilla y León (siglos XI-XIII). Huelva: Universidad de Huelva.

Relaciones histórico-geográficas-estadísticas de los pueblos de España. Reino de Toledo (1951-1963). Carmelo Viñas y Ramón Paz (eds.). Madrid: Centro Superior de Investigaciones Científicas. 
SÁnchez Ferra, Anselmo J. (2013-2014). «El cuento folclórico en Lorca». Revista Murciana de Antropología, 20-21.

SANSTERRE, Jean-Marie (2019). «Le diable, un faux saint, une inventio mensongère... et un franciscain: un étrange récit compilé par Juan Gil de Zamora vers 1280 [= Note de recherche 25, à paraître]». Revue Belge de Philologie et d'Histoire, 97, fasc. 4, p. 3.

Thompson, Stith (1955-1958). Motif-Index of Folk Literature: a Classification of Narrative Elements in Folktales, Ballads, Myths, Fables, Mediaeval Romances, Exempla, Fabliaux, Jest-Books and Local Legends. Bloomington/Indianapolis/Copenhague: Indiana University/Rosenkilde og Bagger.

Uther, Hans-Jörg (2004). The types of International Folktales. A Classification and Bibliography, Based on the System of Antti Aarne and Stith Thompson. Helsinki: Suomalainen Tiedeakatemia/Academia Scientiarum Fennica.

VAldivielso, José de (1854). Vida, excelencias y muerte del gloriosísimo patriarca San José. Cayetano Rosell (ed.). Madrid: Rivadeneyra.

VILLEGAS, Alonso de (1988). Fructus sanctorum y quinta parte del Flossanctorum. Josep Lluis Canet Vallés (ed.). Valencia: LEMIR.

ZAYAs, María de (2007). Novelas amorosas y ejemplares. Julián Olivares (ed.) Madrid: Cátedra. 


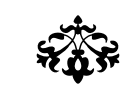

Hechiceras de Cervantes, Faustos hispanos y rosas de invierno

RESUMEN: La hechicera llamada la Camacha de Montilla tenía la capacidad, según Cervantes, de hacer que en diciembre floreciesen rosas frescas en su jardín y de segar trigo en enero. Este artículo analiza esas capacidades mágicas conforme a su documentación en otros relatos de magia, brujería, maravillas, viajes, milagros, épica, romancero, poesía lírica y satírica, etc. Se plantean comparaciones con obras de Ovidio, Séneca, Boccaccio, Lope de Vega, María de Zayas, cronistas de Indias y muchos más autores. Y, sobre todo, se analiza la relación con el ciclo narrativo de Fausto. Se revelan algunas versiones españolas del relato de Fausto anteriores a la documentada en Alemania en 1587.

Palabras clave: Cervantes, Lope de Vega, Fausto, brujería, magia, milagro, maravilla, crónicas de Indias.

\section{CERVANTES' SorceresSes, HisPaniC FAUSTS AND Winter Roses}

Abstract: The witch called la Camacha de Montilla had the capacity, according to Cervantes, to make fresh roses bloom in her garden in December and to reap wheat in January. This essay analyzes these magical capacities according to his documents in other tales of magic, witchcraft, wonders, travels, miracles, epics, romances, lyrical and satirical poetry, etc. Comparisons are made with works by Ovid, Seneca, Boccaccio, Lope de Vega, Maria de Zayas, chroniclers of the Indies and many more authors. Above all, the relationship with Faust's narrative cycle is analysed. Some Spanish versions of Faust's narrative prior to the one documented in Germany in 1587 are revealed.

Keywords: Cervantes, Lope de Vega, Faust, witchcraft, magic, miracle, wonder, chronicles of the Indies. 